\title{
Synopsis of Factors Affecting Hydrogen Storage in Biomass-Derived Activated Carbons
}

\author{
Al Ibtida Sultana, Nepu Saha and M. Toufiq Reza *D \\ Department of Biomedical and Chemical Engineering and Sciences, Florida Institute of Technology, \\ Melbourne, FL 32901, USA; asultana2020@my.fit.edu (A.I.S.); nsaha2019@my.fit.edu (N.S.) \\ * Correspondence: treza@fit.edu; Tel.: +1-321-674-8578
}

Citation: Sultana, A.I.; Saha, N.; Reza, M.T. Synopsis of Factors Affecting Hydrogen Storage in Biomass-Derived Activated Carbons. Sustainability 2021, 13, 1947.

https://doi.org/10.3390/su13041947

Academic Editors: Maurizio Volpe and Deepak Pant

Received: 22 November 2020

Accepted: 6 February 2021

Published: 11 February 2021

Publisher's Note: MDPI stays neutral with regard to jurisdictional claims in published maps and institutional affiliations.

Copyright: (c) 2021 by the authors. Licensee MDPI, Basel, Switzerland. This article is an open access article distributed under the terms and conditions of the Creative Commons Attribution (CC BY) license (https:// creativecommons.org/licenses/by/ $4.0 /)$.

\begin{abstract}
Hydrogen $\left(\mathrm{H}_{2}\right)$ is largely regarded as a potential cost-efficient clean fuel primarily due to its beneficial properties, such as its high energy content and sustainability. With the rising demand for $\mathrm{H}_{2}$ in the past decades and its favorable characteristics as an energy carrier, the escalating USA consumption of pure $\mathrm{H}_{2}$ can be projected to reach 63 million tons by 2050. Despite the tremendous potential of $\mathrm{H}_{2}$ generation and its widespread application, transportation and storage of $\mathrm{H}_{2}$ have remained the major challenges of a sustainable $\mathrm{H}_{2}$ economy. Various efforts have been undertaken by storing $\mathrm{H}_{2}$ in activated carbons, metal organic frameworks (MOFs), covalent organic frameworks (COFs), etc. Recently, the literature has been stressing the need to develop biomass-based activated carbons as an effective $\mathrm{H}_{2}$ storage material, as these are inexpensive adsorbents with tunable chemical, mechanical, and morphological properties. This article reviews the current research trends and perspectives on the role of various properties of biomass-based activated carbons on its $\mathrm{H}_{2}$ uptake capacity. The critical aspects of the governing factors of $\mathrm{H}_{2}$ storage, namely, the surface morphology (specific surface area, pore volume, and pore size distribution), surface functionality (heteroatom and functional groups), physical condition of $\mathrm{H}_{2}$ storage (temperature and pressure), and thermodynamic properties (heat of adsorption and desorption), are discussed. A comprehensive survey of the literature showed that an "ideal" biomass-based activated carbon sorbent with a micropore size typically below $10 \AA$, micropore volume greater than $1.5 \mathrm{~cm}^{3} / \mathrm{g}$, and high surface area of $4000 \mathrm{~m}^{2} / \mathrm{g}$ or more may help in substantial gravimetric $\mathrm{H}_{2}$ uptake of $>10 \mathrm{wt} \%$ at cryogenic conditions $\left(-196^{\circ} \mathrm{C}\right)$, as smaller pores benefit by stronger physisorption due to the high heat of adsorption.
\end{abstract}

Keywords: hydrogen storage; activated carbon; surface morphology; thermodynamics; heat of adsorption

\section{Introduction}

Hydrogen $\left(\mathrm{H}_{2}\right)$ is the most abundant element in the universe. It is also the lightest element with a high energy content (142 MJ/kg of higher heating value), which makes it a sustainable and non-toxic energy carrier [1-5]. With its favorable fuel characteristics, the escalating demand of $\mathrm{H}_{2}$ in the U.S. can be projected to be 63 million tons by 2050, which will be equivalent to $14 \%$ of the total energy demand [6]. Various methods have already been developed for $\mathrm{H}_{2}$ generation, such as natural gas reforming, electrolysis, gasification, etc., and a few methods are in development, such as high-temperature water splitting, photobiological water splitting, etc. [7-15]. Although the current primary source of $\mathrm{H}_{2}$ production is natural gas, it can be produced from coal and biomass.

Despite the tremendous potential of hydrogen generation and its widespread application, $\mathrm{H}_{2}$ transport and storage remain two major challenges. Various efforts have been undertaken to store $\mathrm{H}_{2}$ both chemically (metal hydrides, methanol, ammonia, etc.) [16-21] and physically (activated carbon (ACs) [4,22-29], metal organic frameworks (MOFs) [3034], covalent organic frameworks (COFs) [35,36], etc.). Chemical storage is mainly used for long term $\mathrm{H}_{2}$ storage where a high density of hydrogen can be stored in chemical 
form (e.g., $\mathrm{NH}_{3}$ ). However, the regeneration of $\mathrm{H}_{2}$ after chemical storage is often energy intensive. On the other hand, a short-term $\mathrm{H}_{2}$ storage option with a lower heat of hydrogen regeneration and higher $\mathrm{H}_{2}$ recovery is crucial for vehicles and fuel cells. For fast kinetics and high reversibility of $\mathrm{H}_{2}$ over multiple cycles, physical storage in porous material has proven more economically viable than chemical storage for short-term storage [37,38]. Among the porous materials, the most widely studied $\mathrm{H}_{2}$ storage materials are MOFs and porous AC materials [39-41]. For example, AC material derived from cellulose acetate can store as high as $8.1 \mathrm{wt} \%$ at 20 bar and at $-196{ }^{\circ} \mathrm{C}$ [42]. When comparing materials for physisorption of $\mathrm{H}_{2}, \mathrm{AC}$ adsorbents have several distinct advantages over crystalline materials, which are related to their ease of availability, low cost, and superior chemical, mechanical, and thermal stabilities. In addition, ACs are easy to regenerate, have low densities (lightweight), fast kinetics, and tunable pore structures [3,43]. Most importantly, an abundance of biomass in nature and the configurable properties of ACs during the process of activation for enhanced $\mathrm{H}_{2}$ adsorption have been emphasized in the literature [44-46].

This article presents a profound literature review to distinctly identify the most favorable characteristics of biomass-derived adsorption materials for $\mathrm{H}_{2}$ uptake. As biomassderived AC offers the opportunity to tune its properties, this article thoroughly investigated the following parameters: the surface morphology and functionality of AC, its thermodynamic properties, and the physical conditions while seeking a high $\mathrm{H}_{2}$ uptake by the AC. This article also broadly highlights the recent developments in metal-doped activated carbon composites (spillover mechanism) to shed light on possible material modification in the practical application of hydrogen storage at ambient conditions.

\section{Factors Affecting $\mathbf{H}_{2}$ Storage in Biomass-Derived Activated Carbons}

\subsection{Role of Surface Morphology of Activated Carbons on $\mathrm{H}_{2}$ Storage}

$\mathrm{H}_{2}$ adsorption capacity is governed by the factors that affect the adsorbate-adsorbent interactions. The most important factors in determining adsorptive $\mathrm{H}_{2}$ uptake in porous materials are surface area, micropore volume, and pore size [47-60]. The mechanism for $\mathrm{H}_{2}$ storage by means of physisorption is the van der Waals attraction between the surface of the ACs and the $\mathrm{H}_{2}$ molecules [61]. On the other hand, the van der Waals interaction between the $\mathrm{H}_{2}$ molecules is weak; therefore, to expect a few layers of hydrogen packing onto an adsorbent surface is impractical [62]. As the $\mathrm{H}_{2}$ adsorption on AC will be a monolayer, a large specific surface area (SSA) is found to be beneficial for higher uptake. The ACs derived from different biomasses, along with their physiochemical properties, surface morphology, and hydrogen adsorption capacity at $77 \mathrm{~K}$, are listed in Table 1. The significance of SSA for a substantial $\mathrm{H}_{2}$ uptake is reflected in the increasing tendency from 2.1 to $8.9 \mathrm{wt} \%$ with the increase of SSA from 687 to $3771 \mathrm{~m}^{2} / \mathrm{g}$, as seen in Figure 1, which is also in line with several other literature that reached an analogous conclusion for biomass-derived AC [47-51,53,55,63-65]. From Table 1, to name a few examples, hemp stem, cellulose acetate, and melaleuca bark-derived activated carbons exhibit a trend of an increasing quantity of $\mathrm{H}_{2}$ adsorbed in the range of $1.57-3.28 \mathrm{wt} \%$ (at $1 \mathrm{bar}$ ), 3.1-3.9 $\mathrm{wt} \%$ (at 1 bar), and 1.21-3.91 $\mathrm{wt} \%$ (at $10 \mathrm{bar}$ ) for a corresponding SSA of $922-3241 \mathrm{~m}^{2} / \mathrm{g}, 2001-3771 \mathrm{~m}^{2} / \mathrm{g}$, and $1092-2986 \mathrm{~m}^{2} / \mathrm{g}$, respectively. 


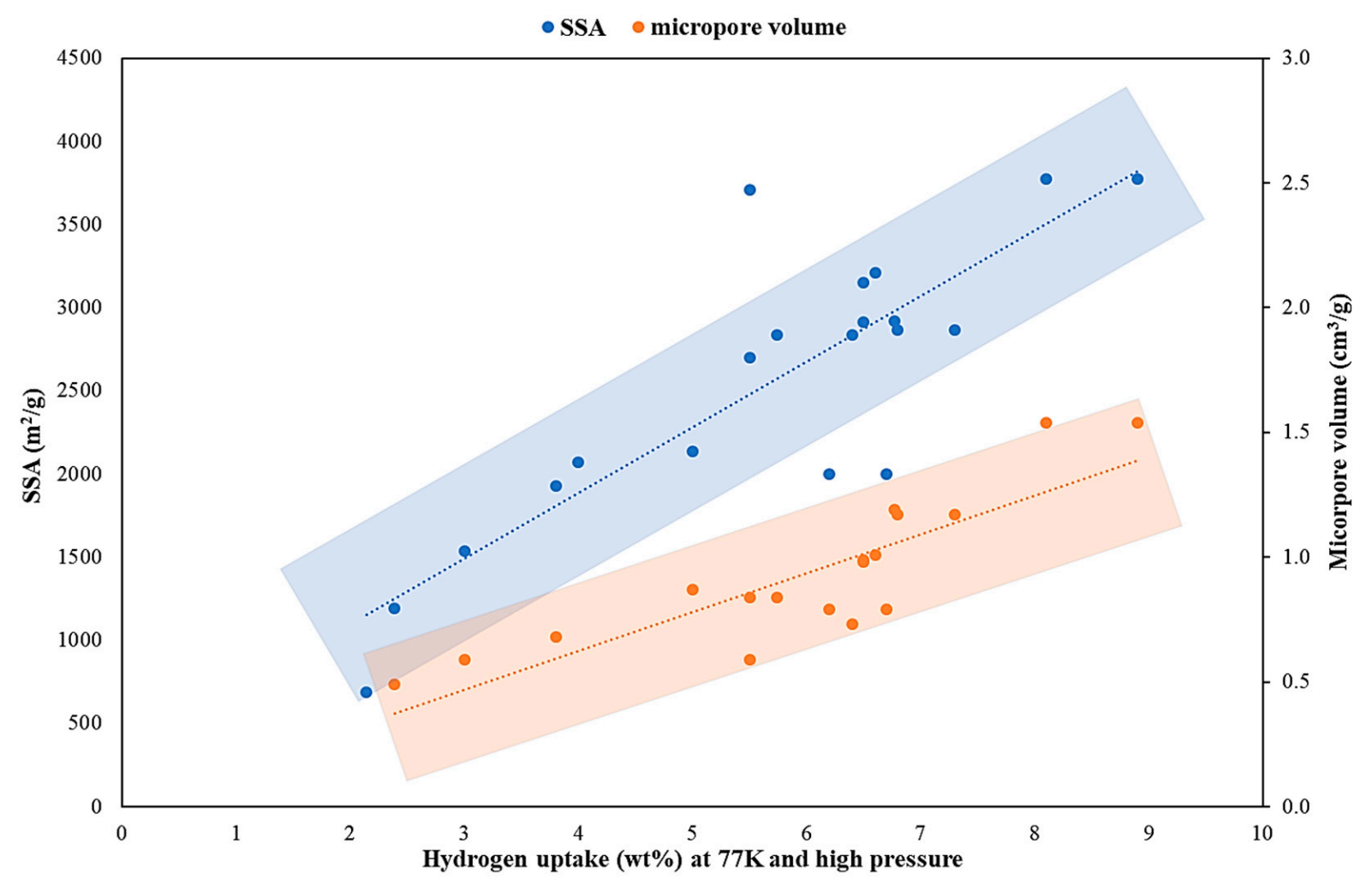

Figure 1. Correlation between the hydrogen uptake capacity at $77 \mathrm{~K}$ with high pressure and the micropore volume and specific surface area (data from Table 1).

However, correlating the $\mathrm{H}_{2}$ uptake solely with SSA might not be adequate to justify the quantity of $\mathrm{H}_{2}$ adsorbed. This is mainly because the different carbon materials exhibit different morphological properties, such as micropore volume, pore size distribution, and surface functionality. For example, it can be observed from Table 1 that the $\mathrm{H}_{2}$ uptake capacity of beer lees-derived AC decreases with the increase in SSA, while doubling the SSA of hemp stem-derived AC barely enhances $\mathrm{H}_{2}$ uptake by $10 \mathrm{wt} \%$. In addition, beer lees and sword-bean shell-derived $\mathrm{ACs}$ have $\mathrm{H}_{2}$ uptake capacities of 2.92 and $2.25 \mathrm{wt} \%$, respectively, despite having a very similar SSA (SSA 1927 and $1930 \mathrm{~m}^{2} / \mathrm{g}$, respectively). A similar observation was reported by Yakobson et al. [62] and Ujjal Kumar Sur [66], where they reported 5.0 and $7.7 \mathrm{wt} \%$ of $\mathrm{H}_{2}$ uptake, respectively, on graphene with a similar SSA $\left(\sim 2600 \mathrm{~m}^{2} / \mathrm{g}\right)$. These examples clearly substantiate the necessity to rather consider the synergistic effect of the significant surface morphological properties of porous ACs.

In addition to SSA, presence of an adequate volume of small pores is another key factor that attributes to $\mathrm{H}_{2}$ uptake. According to the International Union of Pure and Applied Chemistry (IUPAC), the pore sizes of the adsorbent are classified as macropores (pore radius, $r>50 \mathrm{~nm}$ ), which exist at the entrance of the carbon materials and serve as carriers. At the same time, mesopores $(2<\mathrm{r}<50 \mathrm{~nm})$ contribute to adsorption, whereas adsorption itself takes place on the micropores $(\mathrm{r}<2 \mathrm{~nm})$. The interaction energy between the $\mathrm{H}_{2}$ molecules and carbon adsorbents can be enhanced by narrowing the pore size due to overlap of the potential fields from both sides of the pore wall to a degree determined by the pore width [67]. For smaller pores, the overlap of van der Waals potentials due to the atoms of the adjacent walls favors stronger physisorption [59]. The total interaction between the adsorbate molecule and a solid is greater if the molecule can interact with a larger number of surface atoms, as what happens in small pores $[56,68]$. Therefore, smaller pores are more efficient in $\mathrm{H}_{2}$ sorption due to stronger interaction with $\mathrm{H}_{2}$ molecules [68].

The pore size range that is favorable to maximize hydrogen uptake is broadly found to be $0.7-1.5 \mathrm{~nm}$. ACs with a homogenous pore size distribution (PSD) centered across 
a narrow range $(<0.7 \mathrm{~nm})$ are not as efficient $\mathrm{H}_{2}$ adsorbents as it saturates at very low pressures [59]. On the other hand, the contribution of pores larger than $1.5 \mathrm{~nm} \mathrm{in} \mathrm{H}_{2}$ uptake is not significant as the $\mathrm{H}-\mathrm{H}$ interaction inside such large pores are not strong enough. Several experimental results validated that the $\mathrm{H}_{2}$ uptake is rather higher for small pores with the optimum slit pore width of $1.0 \mathrm{~nm}$ or smaller [4,50,52,56-60,69-74]. For instance, Gogotsi et al. reported $\mathrm{H}_{2}$ storage normalized to SSA (also called hydrogen density) for a range of micropore sizes and concluded that the predominant $\mathrm{H}_{2}$ uptake are preferable by a pore size range of below $1 \mathrm{~nm}$ [69]. In addition, several other researchers reached a similar conclusion that the best correlation between $\mathrm{H}_{2}$ uptake and pore range was for pores smaller than $1 \mathrm{~nm}[55,75]$. On the other hand, Cabria et al. presented a thermodynamic model that also showed the optimum pore width to be well below $1 \mathrm{~nm}$ [70]. However, along with the increase in pressure, $\mathrm{H}_{2}$ adsorbed in the micropores tends to be saturated and, to a minor extent, small mesopores between 2 and $5 \mathrm{~nm}$ are then responsible for the remaining $\mathrm{H}_{2}$ uptake capacity $[53,70]$.

Complimentary to the pore size, $\mathrm{H}_{2}$ uptake is associated with the cumulative volume of pores of $<2 \mathrm{~nm}$ in size, which is quantified as a micropore volume and is a measure of the activated carbon's microporosity. Therefore, consistent with the discussion on the "ideal" pore size, micropore volume is another key parameter for $\mathrm{H}_{2}$ storage ability, and a high micropore volume is nevertheless advantageous for higher $\mathrm{H}_{2}$ uptake capacity. There is a linear tendency of increasing the gravimetric $\mathrm{H}_{2}$ uptake of $2.14-8.90 \mathrm{wt} \%$ with an increase in micropore volume from $0.297-1.540 \mathrm{~cm}^{3} / \mathrm{g}$, as shown in Figure 1.

\subsection{Role of Surface Functionality of $\mathrm{AC}$ on $\mathrm{H}_{2}$ Storage}

In addition to surface morphology, surface functionality is another crucial aspect of AC that could enhance the $\mathrm{H}_{2}$ uptake capacity. Since the interaction between adsorbed hydrogen and carbon is weak due to van der Waals interactions, one of the ways to improve the heat of adsorption is via functionalization of the pore surfaces with heteroatoms (e.g., nitrogen, oxygen, etc.) [4,42]. Prior to the discussion of various heteroatoms' effect on the quantity of $\mathrm{H}_{2}$ adsorbed, it is imperative to briefly overview the fate of biomass-derived activated carbons' elemental composition, as listed in Table 1.

As seen in Table 1, although biomass undergoing chemical activation develops a great improvement in the surface morphological factors, the heteroatoms' (nitrogen and oxygen) elemental weight percent shows a significant reduction from the corresponding precursor material. This could be explained by means of findings from Fourier-Transform Infrared Spectroscopy (FTIR) of various such ACs in the literature, where a decreased peak intensity or an even complete disappearance of certain bands, for example, C-N, C-NH-C, hydroxylic $\mathrm{O}-\mathrm{H}$, aromatic carbonyl/carboxyl $\mathrm{C}=\mathrm{O}$, and aliphatic ether and alcohol $\mathrm{O}-\mathrm{H}$, were noted [79-82]. Such a loss of functional groups results from the formation of a fused ring structure that aids in pore formation, by-producing volatile products like $\mathrm{CO}, \mathrm{H}_{2} \mathrm{O}$, and $\mathrm{CO}_{2}$ [83-85]. Removal of hydrogen $(\mathrm{H})$ and oxygen $(\mathrm{O})$ from the precursor during the chemical activation process leads to aromaticity development [86-88]. On the other hand, the formation of cyanide during alkaline activation is responsible for the loss of nitrogen (N) content in the ACs [77]. 
Table 1. The elemental and morphological parameters, with the hydrogen uptake at $77 \mathrm{~K}$, of various biomasses and their corresponding hydrochar and activated carbon.

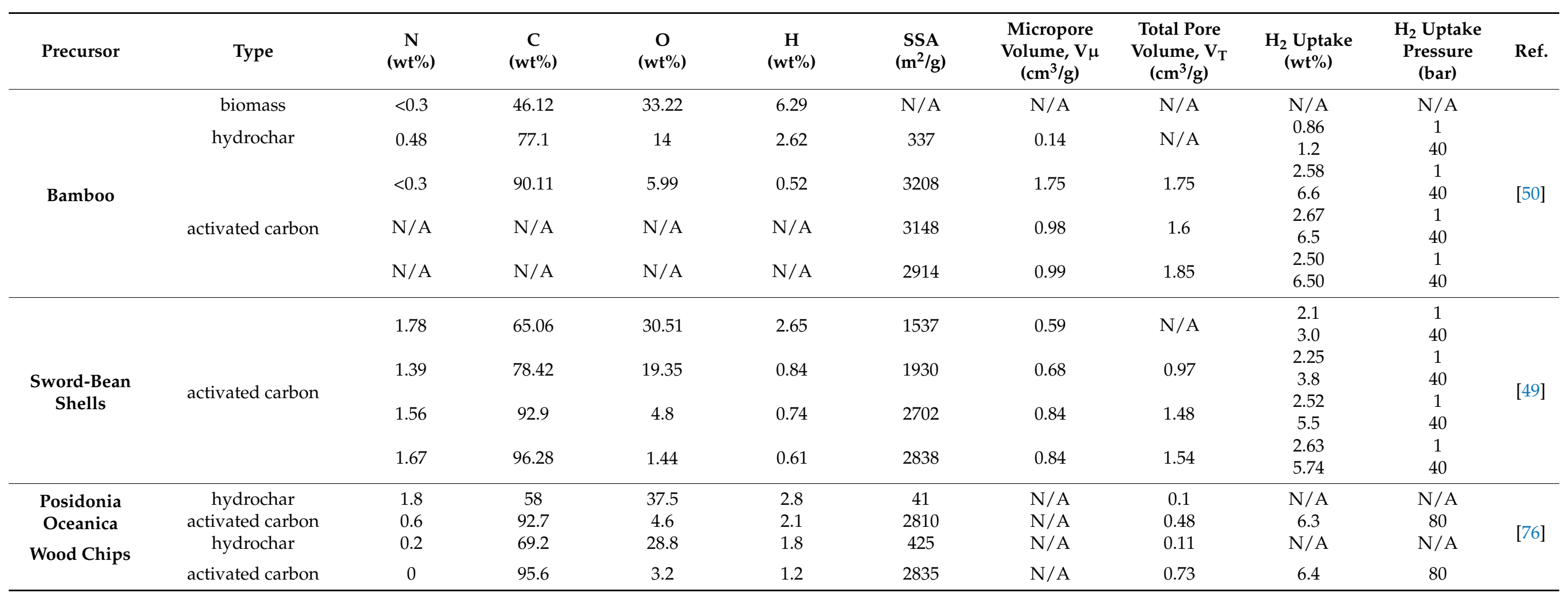


Table 1. Cont.

\begin{tabular}{|c|c|c|c|c|c|c|c|c|c|c|c|}
\hline Precursor & Type & $\underset{(w t \%)}{N}$ & $\underset{(w t \%)}{C}$ & $\underset{(w t \%)}{O}$ & $\underset{(w t \%)}{H}$ & $\begin{array}{c}\text { SSA } \\
\left(\mathrm{m}^{2} / \mathrm{g}\right)\end{array}$ & $\begin{array}{c}\text { Micropore } \\
\text { Volume, V } \mu \\
\left(\mathrm{cm}^{3} / \mathrm{g}\right)\end{array}$ & $\begin{array}{c}\text { Total Pore } \\
\text { Volume, } V_{\mathrm{T}} \\
\left(\mathrm{cm}^{3} / \mathrm{g}\right)\end{array}$ & $\begin{array}{c}\mathrm{H}_{2} \text { Uptake } \\
(\mathrm{wt} \%)\end{array}$ & $\begin{array}{c}\mathrm{H}_{2} \text { Uptake } \\
\text { Pressure } \\
\text { (bar) }\end{array}$ & Ref. \\
\hline \multirow{5}{*}{$\begin{array}{c}\text { Melaleuca } \\
\text { bark }\end{array}$} & biomass & 0.51 & 58.13 & 33.45 & 7.91 & $\mathrm{~N} / \mathrm{A}$ & $\mathrm{N} / \mathrm{A}$ & $\mathrm{N} / \mathrm{A}$ & $\mathrm{N} / \mathrm{A}$ & $\mathrm{N} / \mathrm{A}$ & \multirow{5}{*}[77]{} \\
\hline & \multirow{4}{*}{ activated carbon } & 0.35 & 87.66 & 10.98 & 1.01 & 1092 & 0.4 & 0.46 & 1.21 & 10 & \\
\hline & & 0.28 & 88.69 & 9.6 & 0.89 & 1806 & 0.64 & 0.82 & 2.16 & 10 & \\
\hline & & 0.21 & 91.56 & 7.59 & 0.64 & 3170 & 1.07 & 1.51 & 4.08 & 10 & \\
\hline & & 0.19 & 91.89 & 7.39 & 0.53 & 2986 & 0.86 & 1.63 & 3.91 & 10 & \\
\hline \multirow{9}{*}{$\begin{array}{l}\text { Cellulose } \\
\text { Acetate }\end{array}$} & \multirow{9}{*}{ activated carbon } & \multirow{9}{*}{$\mathrm{N} / \mathrm{A}$} & \multirow{3}{*}{76.1} & \multirow{3}{*}{22.8} & \multirow{4}{*}{1.1} & \multirow{4}{*}{2001} & \multirow{4}{*}{0.79} & \multirow{3}{*}{0.95} & 3.1 & 1 & \multirow{9}{*}{ [4] } \\
\hline & & & & & & & & & 6.2 & 20 & \\
\hline & & & & & & & & & 6.7 & 30 & \\
\hline & & & & & & & & & 3.4 & 1 & \\
\hline & & & 78.3 & 20.6 & 1.1 & 2864 & 1.17 & 1.17 & 6.8 & 20 & \\
\hline & & & & & & & & & 7.3 & 30 & \\
\hline & & & \multirow{3}{*}{81.4} & \multirow{3}{*}{17.9} & \multirow{3}{*}{0.7} & \multirow{3}{*}{3771} & \multirow{3}{*}{1.54} & \multirow{3}{*}{1.54} & 3.9 & 1 & \\
\hline & & & & & & & & & 8.1 & 20 & \\
\hline & & & & & & & & & $\begin{array}{l}0.1 \\
8.9\end{array}$ & 30 & \\
\hline \multirow{3}{*}{ Beer Lees } & \multirow{3}{*}{ activated carbon } & \multirow{3}{*}{$\mathrm{N} / \mathrm{A}$} & \multirow{3}{*}{$\mathrm{N} / \mathrm{A}$} & \multirow{3}{*}{$\mathrm{N} / \mathrm{A}$} & \multirow{3}{*}{$\mathrm{N} / \mathrm{A}$} & 1927 & 0.754 & 0.797 & 2.92 & 1 & \multirow{3}{*}[48]{} \\
\hline & & & & & & 2092 & 0.889 & 1.152 & 2.74 & 1 & \\
\hline & & & & & & 2408 & 1.089 & 1.505 & 2.43 & 1 & \\
\hline \multirow{6}{*}{ Hemp stem } & \multirow{6}{*}{ activated carbon } & \multirow{6}{*}{$\mathrm{N} / \mathrm{A}$} & \multirow{6}{*}{$\mathrm{N} / \mathrm{A}$} & & & 922 & 0.4 & 0.49 & 1.57 & 1 & \\
\hline & & & & & & 1365 & 0.48 & 0.73 & 2.58 & 1 & \\
\hline & & & & & & 1917 & 0.78 & 1.02 & 2.81 & 1 & \\
\hline & & & & $\mathrm{N} / \mathrm{A}$ & $\mathrm{N} / \mathrm{A}$ & 2368 & 0.88 & 1.27 & 2.72 & 1 & [78] \\
\hline & & & & & & 3018 & 0.68 & 1.73 & 2.94 & 1 & \\
\hline & & & & & & 3241 & 0.74 & 1.98 & 3.28 & 1 & \\
\hline
\end{tabular}


However, the question that needs to be addressed is the correlation of $\mathrm{H}_{2}$ uptake with the quantity of various heteroatom and surface functional groups. Such an influence is difficult to assess due to the synergistic effect of the surface properties and surface chemistry on $\mathrm{H}_{2}$ uptake. Simultaneous variation in elemental composition and surface morphology properties limits the ability to independently determine the effect of either variable.

Regarding the effect of oxygen, Blankenship et al. eliminated such ambiguities by comparing ACs with a similar porosity but different oxygen content, which lead to different $\mathrm{H}_{2}$ uptake. The material stored more $\mathrm{H}_{2}$ possibly because of its oxygen-rich nature [42] The enhanced uptake is due to the high binding energy between oxygen and hydrogen, resulting from a higher adsorption energy. Similar findings were confirmed by Shayeganafar and Shahsavari, where they have studied the effect of oxygen content on pillared graphene material on $\mathrm{H}_{2}$ uptake [89]. Nonetheless, challenges are posed due to the contradictory results about the effect of oxygen from various other research works. For instance, Georgakis et al. observed that functional groups containing oxygen induce a decrease in the $\mathrm{H}_{2}$ adsorption capacity, and this effect is more pronounced with the narrow pores. They accounted this behavior mainly to three factors, namely, an increase in weight due to oxygen, steric hindrance effects, and weaker oxygen-hydrogen interactions compared to carbon-hydrogen [90]. Conversely, few other research groups concluded that the oxygen groups do not affect $\mathrm{H}_{2}$ uptake as no significant differences were detected by comparing its capacity with that of pristine carbons [89,91].

Regarding the effect of nitrogen, high $\mathrm{N}$-doping is beneficial for $\mathrm{H}_{2}$ adsorption at low pressure, but it is detrimental at high pressure [43]. At low pressure, $\mathrm{H}_{2}$ is mainly adsorbed onto the carbon atoms neighboring the nitrogen. However, at high pressure, the presence of nitrogen may reduce the interaction between hydrogen and the carbon surface, thus influencing the overall $\mathrm{H}_{2}$ adsorption capacity $[43,92,93]$. On the other hand, at room temperature, doped heterogeneous nitrogen atoms increase the heat of adsorption of the $\mathrm{H}_{2}$ which improves the $\mathrm{H}_{2}$ storage capacity [56]. A nitrogen atom can attract the electrons of the neighboring carbon atom, leading to an electron deficiency of carbon and high $\mathrm{H}_{2}$ adsorption. On the other hand, a higher nitrogen content negatively affects the $\mathrm{H}_{2}$ adsorption due to the decrease in adsorption energy caused by the adsorption of $\mathrm{H}_{2}$ on both the nitrogen atom and the neighboring carbon atom [94].

From the above discussion, it is imperative to find out the optimum ratio of $\mathrm{N} / \mathrm{C}$ at all conditions relevant to storage. Although it was found that the $\mathrm{H}_{2}$ storage capacity is significantly suppressed, with an increase in the acidic group amounts [54,95], considering the controversial opinions about the influence of the oxygenated functional groups on $\mathrm{H}_{2}$ uptake, quantifying and correlating the effect of various heteroatoms containing surface functional groups with $\mathrm{H}_{2}$ uptake is yet to be explored. It can also be inferred that $\mathrm{H}_{2}$ uptake might improve by increasing the heat of adsorption with the necessary doping or functionalization, but that must not pose any negative effect on the surface morphological properties of the adsorbate. More studies are required to assess the discrete effect of heteroatoms on the carbon-hydrogen heat of adsorption by ensuring all other relevant and influencing surface parameters remain the same at all conditions.

\subsection{Role of Physical Conditions on $\mathrm{H}_{2}$ Storage}

The specific surface area and the microporous volume affect the $\mathrm{H}_{2}$ adsorption capacity and, generally, $\mathrm{H}_{2}$ uptake increases with the increase of these properties. Besides these, the adsorption temperature and pressure are also important parameters that influence the $\mathrm{H}_{2}$ adsorption capacity. A summary of $\mathrm{H}_{2}$ storage at different temperatures and pressure in biomass-based ACs is shown in Table 2. 
Table 2. Hydrogen storage in biomass-derived activated carbon (activated using $\mathrm{KOH}$ ) at various temperatures and pressures.

\begin{tabular}{|c|c|c|c|c|c|c|}
\hline Precursor & $\begin{array}{l}\text { Surface Area } \\
\left(\mathrm{m}^{2} / \mathrm{g}\right)\end{array}$ & $\begin{array}{c}\text { Micropore } \\
\text { Volume } \\
\left(\mathrm{cm}^{3} / \mathrm{g}\right)\end{array}$ & $\begin{array}{c}\text { Temperature } \\
\text { (K) }\end{array}$ & $\begin{array}{l}\text { Pressure } \\
\text { (bar) }\end{array}$ & $\begin{array}{c}\mathrm{H}_{2} \text { Storage } \\
(\mathrm{wt} \%)\end{array}$ & Ref. \\
\hline \multirow{4}{*}{ Cellulose } & \multirow{4}{*}{3771} & \multirow{4}{*}{-} & 77 & 1 & 3.90 & \multirow{2}{*}{ [4] } \\
\hline & & & 77 & 20 & 8.10 & \\
\hline & & & 298 & 20 & 0.50 & [96] \\
\hline & & & 77 & 1 & 1.48 & \\
\hline \multirow[t]{3}{*}{ Olive stone } & \multirow[t]{3}{*}{1269} & \multirow[t]{3}{*}{0.48} & 77 & 25 & 6.11 & \multirow[t]{3}{*}{ [59] } \\
\hline & & & 298 & 200 & 1.22 & \\
\hline & & & 77 & 1 & 2.71 & \\
\hline \multirow[t]{3}{*}{ Chitosan } & \multirow[t]{3}{*}{2919} & \multirow[t]{3}{*}{1.19} & 77 & 20 & 6.77 & \multirow[t]{3}{*}{ [55] } \\
\hline & & & 77 & 40 & 5.01 & \\
\hline & & & 77 & 1 & 1.23 & \\
\hline \multirow[t]{2}{*}{ Olive pomace } & \multirow{2}{*}{1192} & \multirow[t]{2}{*}{0.49} & 77 & 40 & 2.39 & \multirow[t]{2}{*}{ [97] } \\
\hline & & & 298 & 180 & 0.45 & \\
\hline \multirow{3}{*}{ Fungi } & \multirow{3}{*}{2137} & \multirow{3}{*}{0.87} & 77 & 1 & 2.40 & \multirow{3}{*}{ [58] } \\
\hline & & & 77 & 20 & 5.00 & \\
\hline & & & 77 & 1 & 3.20 & \\
\hline \multirow[t]{3}{*}{ Corncob } & \multirow[t]{3}{*}{3708} & \multirow[t]{3}{*}{0.59} & 77 & 40 & 5.50 & \multirow[t]{3}{*}{ [98] } \\
\hline & & & 298 & 164 & 1.05 & \\
\hline & & & 77 & 1 & 2.55 & \\
\hline \multirow[t]{4}{*}{ Wood chips } & \multirow[t]{3}{*}{2835} & \multirow[t]{3}{*}{0.73} & 77 & 80 & 6.40 & \multirow[t]{3}{*}{ [76] } \\
\hline & & & 298 & 80 & 0.55 & \\
\hline & & & 303 & 60 & 1.36 & \\
\hline & \multirow{3}{*}{1784} & \multirow{3}{*}{0.64} & 323 & 60 & 1.14 & \\
\hline \multirow[t]{2}{*}{ Tamarind seeds } & & & 348 & 60 & 0.88 & [99] \\
\hline & & & 373 & 60 & 0.81 & \\
\hline & & & 77 & 1 & 1.97 & \\
\hline Empty fruit bunch & 687 & 0.30 & 77 & 20 & 2.14 & [100] \\
\hline & & & 77 & 40 & 4.00 & [51] \\
\hline Coffee bean waste & 2070 & 1.1 & 298 & 12 & 1.10 & [b1] \\
\hline
\end{tabular}

It can be observed from Table 2 that, in order to increase the $\mathrm{H}_{2}$ storage capacity of the material, one should operate at a lower temperature and higher pressure, no matter what the precursor is. This is due to the physisorption nature of the $\mathrm{AC}$ materials, with van der Waals attraction as the driving force. The pores are nearly saturated at high pressures, which lead the greater $\mathrm{H}_{2}$ uptake. On the other hand, favorability at lower temperatures can be explained by comparing the enthalpy of the adsorption, which is weak compared to the kinetic energy of the molecules at ambient conditions [101]. At low temperatures, the kinetic energy of $\mathrm{H}_{2}$ is low, which makes adsorption easier onto the walls of the pores of the ACs, resulting in higher $\mathrm{H}_{2}$ uptake [51]. Contrarily, with the increase in temperature, the kinetic energy of the $\mathrm{H}_{2}$ increased and required more energy to adsorb [68]. For example, Chahine and Bose found that lowering the storage temperature from ambient temperature ( $293 \mathrm{~K}$ ) to $175 \mathrm{~K}$ increased the $\mathrm{H}_{2}$ adsorption by a factor of 5 , and by a factor of 15 when the adsorption temperature is further lowered to $77 \mathrm{~K}$ [102].

\subsection{Role of Thermodynamic Properties on $\mathrm{H}_{2}$ Storage}

A higher heat of the adsorption, which translates to a stronger hydrogen attachment to the adsorbent, results in a higher $\mathrm{H}_{2}$ coverage of the adsorbent surface, if sorption sites are available $[67,78]$. Yushin et al. confirmed it experimentally where $\mathrm{H}_{2}$ uptake per SSA increases with the integrated average heat of adsorption [75]. The heat of adsorption of carbon-based material with $\mathrm{H}_{2}$ adsorbed at ranges from $2-9 \mathrm{~kJ} / \mathrm{mol}$, which is considered to be weak $[17,79,80]$. However, $\mathrm{H}_{2}$-framework interactions with the heat of adsorption enthalpies in the range of $15-25 \mathrm{~kJ} / \mathrm{mol}$ are optimal targets for $\mathrm{H}_{2}$ storage at near-ambient conditions, which correspond to an intermediate interaction ranging from 
stronger physisorption to weaker chemisorption [81]. Although $\mathrm{H}_{2}$ uptake depends on the choice of adsorbent, operating temperature, and pressure, it might be presumed that those parameters eventually affect the interaction energy. Hence, the $\mathrm{H}_{2}$ uptake capacity is predominantly governed by the heat of adsorption.

For the adsorbent materials, the $\mathrm{H}_{2}$ uptake capacity decreases with increasing temperature, where the strength of this decrease is determined by the heat of adsorption. Although the shapes of the isotherms are usually similar, the maximum $\mathrm{H}_{2}$ uptake at high pressure and the slope of the isotherm at low pressures depend on the type of material, where the latter is also dependent on the heat of adsorption [103].

In addition, a high heat of adsorption is related to small pore size and the active sites being located at the edge orientation of the microdomains [43]. Surface energetic heterogeneity of the ACs can be understood from the adsorption energy distribution that has a close connection with the pore size distribution [48]. With a decreasing pore size, the absolute values of the heat of adsorption increase, indicating an increase in the interactions between $\mathrm{H}_{2}$ and the framework structures. Several authors reached a similar conclusion, where they attributed the high heat of adsorption to a very small pore size [23,103-105]. For example, Jhung et al. illustrated the effect of pore size on the relative adsorption capacity per unit pore volume and the isosteric heat of the adsorption, where both decreased as the pore size diminished [104].

On the other hand, the heat of adsorption is also affected by surface functionality, which could be due to the effect on the adsorbate-adsorbent interaction. For example, Sevilla et al. found this for two different samples with similar surface morphological properties, but where the difference in oxygen content played a role in determining the strength of the interaction between the adsorbate and adsorbent. The sample with a higher oxygen content $(7.1 \mathrm{wt} \%)$ has a lower heat of adsorption and hydrogen uptake than the sample with a lower oxygen content (5.2 wt\%) [23]. In another study, Gogotsi et al. found that a slight increase in $\mathrm{H}_{2}$ uptake corresponds to the increase in heat of adsorption due to the removal of functionality from the surface of the adsorbent via vacuum annealing [69].

Most studies focus on high pressure storage but, for applicability, deliverable capacity plays an important role in determining the true ability to store usable hydrogen, which is the amount of hydrogen adsorbed at high pressure minus the amount adsorbed at the discharge pressure. For practical applications, if the heat of the interaction is substantially high, the great affinity will eventually lead to a large amount of residual adsorptive at the delivery pressure, which will reduce its deliverable capacity. Bhatia and Myers derived an optimum adsorption enthalpy change $\Delta \mathrm{H}_{\mathrm{opt}}^{\circ}$, which represents the average or integral heat of adsorption for a delivery cycle, with the maximum delivery between two pressure points $\left(\mathrm{P}_{1}\right.$ and $\left.\mathrm{P}_{2}\right)$ at a given temperature $(\mathrm{T})$ and the entropy change $\left(\Delta \mathrm{S}^{\circ}\right)$ relative to the standard pressure $\left(\mathrm{P}_{\mathrm{o}}\right)$ and ideal gas constant $(\mathrm{R})$ [106]. For this equation, the absolute value is equal to the isosteric heat and it was derived assuming the adsorbent as homogenous with the adsorption isotherm type of Langmuir [68].

$$
\Delta \mathrm{H}_{\mathrm{opt}}^{\circ}=\mathrm{T} \Delta \mathrm{S}^{\circ}+\frac{\mathrm{RT}}{2} \ln \left(\frac{\mathrm{P}_{1} \mathrm{P}_{2}}{\mathrm{P}_{\mathrm{o}}^{2}}\right)
$$

Using this equation for a delivery cycle, exemplary reasonable values of adsorption and desorption pressures may be taken as $\mathrm{P}_{1}=30$ bar and $\mathrm{P}_{2}=1.5$ bar, respectively; $\Delta S^{\circ}=-8 \mathrm{R}$ (where, the unit of $\mathrm{R}$ is J.mol ${ }^{-1} \cdot \mathrm{K}^{-1}$ ) for a variety of adsorbents, which upon substitution in equation 1 yields $\Delta \mathrm{H}_{\mathrm{opt}}^{\circ}$ as $-15.1 \mathrm{~kJ} / \mathrm{mol}$ at $\mathrm{T}=298 \mathrm{~K}$ and $\mathrm{P}_{0}=1 \mathrm{bar}$.

Combining the above discussions, it can be concluded that $\mathrm{H}_{2}$ uptake capacity is ultimately driven by its microporous structure, with a small pore size enhancing the interaction energy. $\mathrm{H}_{2}$ uptake capacity is also determined by the surface functionality, although a considerable amount of research has not been done yet for biomass-derived ACs, with some controversial findings of the negative effect of heteroatoms, such as oxygen and/or nitrogen. Additionally, $\mathrm{H}_{2}$ uptake is undoubtedly related to the storage temperature, which shows a decrease with increasing temperature due to the weak heat 
of adsorption. Thus, the heat of adsorption might be the fundamental determinant of $\mathrm{H}_{2}$ uptake capacity, which is favorable at cryogenic conditions. However, for the purpose of practical application in the prospective hydrogen economy, the scientific community is also pursuing high hydrogen uptake at an ambient condition, where the optimum heat of energy is approximated to be in the range of $15-25 \mathrm{~kJ} / \mathrm{mol}$, which can be attained by enhancing the physisorption process by further improving the storage material.

\section{Recent Advances in Material Development}

The hydrogen storage capacity at room temperature on ACs is still challenging [107-109]. A promising way to increase the $\mathrm{H}_{2}$ storage capacity is through surface modifications by promoting the spillover mechanism. The $\mathrm{H}_{2}$ spillover process could be described in the three steps shown in Figure 2. In the first step, adsorption of molecular $\mathrm{H}_{2}$ occurred on the catalyst surface. Dissociation of molecular $\mathrm{H}_{2}$ on the catalyst surface takes place in the following step. Finally, the diffusion of dissociated atomic hydrogen occurred on the catalyst and support surface. In this case, a metal (dissociation source) nanoparticle (e.g., $\mathrm{Pt}, \mathrm{Pd}, \mathrm{Ni}, \mathrm{Ru}$, and $\mathrm{Co}$ ) is loaded onto the surface of the carbon materials (receptor). The metal nanoparticles are additives that act as a catalytic active center for the dissociation of hydrogen during the process. In this case, the carbon receptor plays an important role as it provides the adsorption sites for the spillover hydrogen [110]. Spillover might be influenced by morphological factors, including porosity in the carbon skeleton, as migration needs metal-carbon contacts to occur. In addition, the number and quality of these bridges also depend on the structural and morphological properties of the metal-AC composites. In general, smaller particle composites have higher catalytic reactivity and is better for adsorption and dissociation of molecular $\mathrm{H}_{2}$ on the composite adsorbent surface. For example, Zielinski et al. experimentally found that there is no correlation between $\mathrm{H}_{2}$ uptake and the metal surface area [111]. However, they observed that the hydrogen adsorption declined with the decrease in SSA of the metal-AC composite despite having a higher metal surface area due to an increase in metal content. There are various techniques to prepare metal-carbon nanocomposites, such as wet impregnation, plasma reduction, sputtering, electrodeposition, thermal evaporation, etc. The pros and cons of these processes are discussed elsewhere [54,109,112-119].
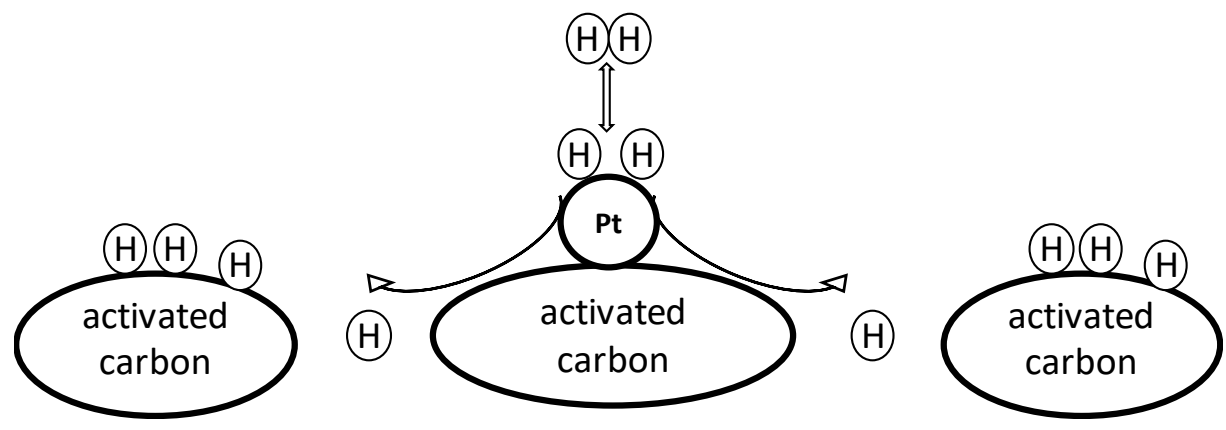

Figure 2. Spillover mechanism in the Pt-AC composite [120].

It can be interpreted from the literature that the surface diffusion of atomic hydrogen could be the rate-determining step for $\mathrm{H}_{2}$ adsorption [121,122]. Thus, the kinetics of $\mathrm{H}_{2}$ adsorption via hydrogen spillover may be characterized by a surface diffusivity (D) or diffusion time constant $\left(D / R^{2}\right.$, where $R$ is the characteristic radius of the sphere for diffusion) [121]. Due to the strong binding energy between the atomic hydrogen and carbon surface, it is difficult to make the atomic hydrogen diffuse over longer distances. The best method is to make more catalyst clusters dispersed on the interior surface of the nanopore of the porous storage support as it will assist atomic hydrogen diffusing into deep sites and enhance $\mathrm{H}_{2}$ uptake [123]. 
However, it is difficult to achieve desirable dispersion at a high metal loading due to the aggregation of the metal. It lowers the SSA of the composite, which adversely impacts the $\mathrm{H}_{2}$ storage capacity [124-126]. Some studies on metal-doped carbons reported that the existence of functional groups can facilitate the dispersion of fine metal catalysts that play an important role in the surface diffusion of the spillover $\mathrm{H}$ atoms to enhance the "chemical" adsorption of $\mathrm{H}_{2}$ [127-130]. The oxygen functional groups in the spillover process act as a direct adsorption site (reversible or irreversible), enhancing the formation of an island of the spilled-over $\mathrm{H}$ atoms around the oxygen groups [127] and facilitating the surface diffusion and favorable adsorption of the atomic hydrogen (due to the continuous network or spatial dispersion of the oxygen groups) [128]. On the other hand, doping of $\mathrm{N}$ could create defects on the composite, helping to reduce the metal particle size and hence better dispersion. In addition, it enhances the spillover process by working as a hydrogen atom receptor. For example, Zhao et al. observed enhancement of $\mathrm{H}_{2}$ storage capacity by around $10 \mathrm{wt} \%$ at room temperature after doping the nitrogen with a $\mathrm{Pt}-\mathrm{AC}$ composite, provided that the $\mathrm{Pt}$ composition remained the same in the composite [126].

The enhancement in hydrogen uptake due to doping with various metals is shown in Table 3. It shows that, with the decrease in Pt content by half, $\mathrm{H}_{2}$ uptake is enhanced by a factor of three. This could be explained by Pt being more reactive for molecular $\mathrm{H}_{2}$ that inhibits dissociation of atomic hydrogen to move and diffuse into a porous carbon surface [131,132]. Unlike the use of precious metals like Pt for the purpose of doping, $\mathrm{Ni}$ has also been used. $\mathrm{Ni}$ is a less expensive metal but sufficiently active for $\mathrm{H}_{2}$ uptake. $\mathrm{H}_{2}$ adsorption is higher in case of Ni-AC because van der Waals interactions are higher between the Ni nanoparticles and the hydrogen molecules, which is the first step for the spillover mechanism $[115,133,134]$. As a result, Ni nanoparticles assist in the dissociation of hydrogen molecules into hydrogen atoms. However, $\mathrm{H}_{2}$ storage capacity of the $\mathrm{Ni} / \mathrm{AC}$ nanocomposites depends strongly on the Ni amount, as can be seen in Table 3 , in that with just a $6 \%$ increase in Ni content, $\mathrm{H}_{2}$ uptake declined by $33 \%$. This could be explained by the adverse effect on the hydrogen spillover due to the agglomeration of Ni nanoparticles, possibly covering the AC surface and isolating it from hydrogen exposure, thereby blocking the access to porosity [109].

Table 3. Hydrogen uptake comparison of various metal-doped activated carbons.

\begin{tabular}{|c|c|c|c|c|c|}
\hline \multirow{2}{*}{$\begin{array}{l}\text { Storing } \\
\text { Condition }\end{array}$} & \multirow{2}{*}{$\begin{array}{l}\text { Metal } \\
\text { Content }\end{array}$} & \multicolumn{2}{|c|}{$\mathrm{H}_{2}$ Storage $(\mathbf{w t} \%)$} & \multirow{2}{*}{$\begin{array}{l}\text { Change in } \\
\text { Uptake (\%) * }\end{array}$} & \multirow{2}{*}{ Ref. } \\
\hline & & Without Dopant & With Dopant & & \\
\hline \multirow{4}{*}{298 K $10 \mathrm{MPa}$} & $10 \mathrm{wt} \% \mathrm{Pd}$ & 0.6 & 1.80 & 200 & [135] \\
\hline & $6 \mathrm{wt} \% \mathrm{Pt}$ & 0.84 & 1.34 & 60 & [136] \\
\hline & $5.6 \mathrm{wt} \% \mathrm{Pt}$ & 0.60 & 1.20 & 100 & [137] \\
\hline & $3 w t \% P t$ & 0.30 & 0.90 & 200 & {$[114]$} \\
\hline $298 \mathrm{~K} 3 \mathrm{MPa}$ & $1 \mathrm{wt} \% \mathrm{Ni}$ & 0.15 & 0.53 & 253 & [111] \\
\hline $298 \mathrm{~K} 20 \mathrm{MPa}$ & $9.7 \mathrm{wt} \% \mathrm{Ni}$ & very low & 1.00 & $\mathrm{~N} / \mathrm{A}$ & [138] \\
\hline $303 \mathrm{~K} 6 \mathrm{MPa}$ & $10 \mathrm{wt} \% \mathrm{Pd}$ & 0.41 & 0.53 & 29 & [54] \\
\hline $303 \mathrm{~K} 5 \mathrm{MPa}$ & $10 \mathrm{wt} \% \mathrm{Ni}$ & 0.82 & 1.60 & 95 & [109] \\
\hline $298 \mathrm{~K} 18 \mathrm{MPa}$ & $\begin{array}{c}2.5 \mathrm{wt} \% \\
\mathrm{Pd} / \mathrm{Pt}\end{array}$ & 1.00 & 1.65 & 65 & [131] \\
\hline $298 \mathrm{~K} 25 \mathrm{MPa}$ & $1.86 w \mathrm{t} \% \mathrm{Pd}$ & 0.60 & 1.40 & 133 & [139] \\
\hline 77 K 40 bar & $1.73 w \mathrm{t} \% \mathrm{Pd}$ & 2.39 & 2.46 & 3 & [97] \\
\hline 298 K 180 bar & $1.73 \mathrm{wt} \% \mathrm{Pd}$ & 0.45 & 0.52 & 16 & [97] \\
\hline \multirow[t]{2}{*}{298 K 180 bar } & $1.1 \mathrm{wt} \% \mathrm{Pt}$ & 0.45 & 0.53 & 18 & [97] \\
\hline & $1.8 w \mathrm{t} \% \mathrm{Ni}$ & & 0.13 & 2 & \\
\hline \multirow{3}{*}{298 K 25 bar } & $1.75 \mathrm{wt} \% \mathrm{Cu}$ & & 0.13 & 6 & \\
\hline & $3.71 w t \% \mathrm{Ag}$ & 0.126 & 0.13 & 3 & [97] \\
\hline & $1.91 \mathrm{wt} \% \mathrm{Ni}$ & & 0.09 & -31 & \\
\hline
\end{tabular}

* Changes with dopant were calculated with respect to without dopant.

Thus, it can be summarized that a great potential of enhanced $\mathrm{H}_{2}$ uptake at room temperature can be envisioned using metal-AC composites. The surface porosity of the 
metal-AC composite positively affects the $\mathrm{H}_{2}$ uptake capacity unlike an increase in metal surface area. In terms of surface functionality, oxygen functional groups seem to improve the $\mathrm{H}_{2}$ uptake ability of the composite. A similar effect of nitrogen doping was observed but the effect on $\mathrm{H}_{2}$ uptake of the nitrogen functional groups in such composites is yet to be analyzed. A high metal level also shows a detrimental effect on hydrogen uptake due to metal aggregation. This calls for further analysis in determining the optimum concentration of the metal in a composite material.

\section{Conclusions}

This article discussed the key role of surface morphology as well as surface functionality on the substantial $\mathrm{H}_{2}$ uptake capacity of biomass-derived $\mathrm{AC}$ at various storage conditions. It can be concluded that the $\mathrm{H}_{2}$ adsorption capacity on biomass-derived AC depends on surface porosity, surface functionality, and the heteroatoms' content. The synergistic effect of these parameters affects the heat of adsorption, which is ultimately the determining factor of $\mathrm{H}_{2}$ uptake.

Although a considerable amount of work has been done to exploit the standpoint of biomass-derived $\mathrm{AC}$ in $\mathrm{H}_{2}$ storage ability, some significant voids still remain, which need to be addressed. These voids need to be explored in the future for its profound usage. For example, a plethora of lignocellulosic biomass is used as a suitable feedstock for AC preparation, where the analysis of the influence of its components (xylan, lignin, cellulose, etc.) on the adsorption capacity of $\mathrm{H}_{2}$ is still unknown. On the other hand, precursor materials may also contain significant proportions of inorganics, but their effect on $\mathrm{H}_{2}$ uptake has not been analyzed. The crystallinity of the various biomass-derived activated carbon is also an important structural parameter to be studied, as the literature shows that carbon's crystalline structure enhances the hydrogen adsorption capacity in case of hydrogen adsorption in graphene sheets [29].

In addition, the effect of surface functionality and the content of heteroatoms need more extensive analysis in terms of physical chemistry to understand the bonding and subsequent quantitative effect of those on the heat of adsorption. Studying the individual effect of various functional groups on the integrated heat of absorption might also provide insight into the principal influence of these groups on the interaction energy of hydrogen with carbon.

Lee and Park showed an enhancement of $\mathrm{H}_{2}$ uptake by 5 times in an MOF-AC composites with metal doping compared to the corresponding pristine MOF [111]. This highlights the necessity to investigate various combinations of metal and biomass-derived ACs, which might have very high spillover as well as surface properties to improve hydrogen storage significantly at ambient conditions.

Finally, another significant gap in the literature that exists is assessing the mechanical strength of materials after a high number of gas storage cycles, such that it can be implemented for the practical application of hydrogen storage. Although Pedicini et al. [48] have shown stability for six cycles of $\mathrm{H}_{2}$ storage, it is important to study longer cyclic storage with both adsorption and desorption capacity to assert an approximate structural strength of the material. Techniques to improve the strength of the ultra-micropores should be explored to prevent pore collapse and hence better cyclability of the material. It is also important to pay attention to lower the activation energy in the desorption of hydrogen for an improved usable capacity of the material. Furthermore, the adsorption kinetics in biomass-derived activated carbons need to be studied so that materials can be developed that have a minimum fill time with fully reversible characteristics.

Author Contributions: Conceptualization, A.I.S., N.S. and M.T.R.; validation, N.S. and M.T.R.; formal analysis, A.I.S.; investigation, A.I.S.; resources, A.I.S.; data curation, A.I.S.; writing-original draft preparation, A.I.S.; writing-review and editing, A.I.S. and N.S.; visualization, N.S. and M.T.R.; supervision, N.S. and M.T.R.; project administration, M.T.R.; funding acquisition, M.T.R. All authors have read and agreed to the published version of the manuscript. 
Funding: The research is funded by the National Science Foundation under Grant No. 1856058.

Institutional Review Board Statement: Not applicable.

Informed Consent Statement: Not applicable.

Acknowledgments: The authors acknowledge Kyle McGaughy, Tahmid Islam, and Thomas Quaid from Biofuels lab at Florida Institute of Technology for their valuable inputs in the manuscript to make it more organized.

Conflicts of Interest: The authors declare no conflict of interest.

\section{References}

1. Moriarty, P.; Honnery, D. Hydrogen's role in an uncertain energy future. Int. J. Hydrog. Energy 2009, 34, 31-39. [CrossRef]

2. Turner, J.A. A Realizable renewable energy future. Science 1999, 285, 687-689. [CrossRef] [PubMed]

3. Schlapbach, L.; Züttel, A. Hydrogen-storage materials for mobile applications. Mater. Sustain. Energy 2011, 265-270. [CrossRef]

4. Blankenship Ii, T.S.; Balahmar, N.; Mokaya, R. Oxygen-rich microporous carbons with exceptional hydrogen storage capacity. Nat. Commun. 2017, 8, 1545. [CrossRef] [PubMed]

5. Møller, K.T.; Jensen, T.R.; Akiba, E.; Li, H. Hydrogen-A Sustainable Energy Carrier. Prog. Nat. Sci. Mater. Int. 2017, 27, 34-40. [CrossRef]

6. Road Map to a US Hydrogen Economy. Available online: https://cafcp.org/sites/default/files/Road $\% 2 \mathrm{BMap} \% 2 \mathrm{Bto} \% 2 \mathrm{Ba} \%$ 2BUS\%2BHydrogen\%2BEconomy\%2BFull\%2BReport.pdf (accessed on 9 November 2020).

7. Koroneos, C.; Dompros, A.; Roumbas, G. Hydrogen production via biomass gasification-A life cycle assessment approach Chem. Eng. Process. Process Intensif. 2008, 47, 1261-1268. [CrossRef]

8. Kalamaras, C.M.; Efstathiou, A.M. Hydrogen Production Technologies: Current State and Future Developments. Available online: https:/ / www.hindawi.com/journals / cpis/2013/690627/ (accessed on 20 November 2020).

9. Turner, J.A. Sustainable hydrogen production. Science 2004, 305, 972-974. [CrossRef]

10. Kapdan, I.K.; Kargi, F. Bio-Hydrogen production from waste materials. Enzym. Microb. Technol. 2006, 38, 569-582. [CrossRef]

11. Dincer, I.; Acar, C. Review and evaluation of hydrogen production methods for better sustainability. Int. J. Hydrog. Energy 2015, 40, 11094-11111. [CrossRef]

12. Acar, C.; Dincer, I. Comparative Assessment of hydrogen production methods from renewable and non-renewable sources. Int. J. Hydrog. Energy 2014, 39, 1-12. [CrossRef]

13. Kothari, R.; Buddhi, D.; Sawhney, R.L. Comparison of Environmental and economic aspects of various hydrogen production methods. Renew. Sustain. Energy Rev. 2008, 12, 553-563. [CrossRef]

14. Nikolaidis, P.; Poullikkas, A. A comparative overview of hydrogen production processes. Renew. Sustain. Energy Rev. 2017, 67, 597-611. [CrossRef]

15. Holladay, J.D.; Hu, J.; King, D.L.; Wang, Y. An Overview of hydrogen production technologies. Catal. Today 2009, 139, 244-260. [CrossRef]

16. Eberle, U.; Felderhoff, M.; Schüth, F. Chemical and physical solutions for hydrogen storage. Angew. Chem. Int. Ed. 2009, 48, 6608-6630. [CrossRef] [PubMed]

17. Keaton, R.J.; Blacquiere, J.M.; Baker, R.T. Base metal catalyzed dehydrogenation of ammonia-borane for chemical hydrogen storage. J. Am. Chem. Soc. 2007, 129, 1844-1845. [CrossRef]

18. Bluhm, M.E.; Bradley, M.G.; Butterick, R.; Kusari, U.; Sneddon, L.G. Amineborane-based chemical hydrogen storage: enhanced ammonia borane dehydrogenation in ionic liquids. J. Am. Chem. Soc. 2006, 128, 7748-7749. [CrossRef]

19. Vajo, J.J.; Olson, G.L. Hydrogen storage in destabilized chemical systems. Scr. Mater. 2007, 56, 829-834. [CrossRef]

20. Zhu, Q.-L.; Xu, Q. Liquid organic and inorganic chemical hydrides for high-capacity hydrogen storage. Energy Environ. Sci. 2015, 8, 478-512. [CrossRef]

21. Ren, J.; Musyoka, N.M.; Langmi, H.W.; Mathe, M.; Liao, S. Current research trends and perspectives on materials-based hydrogen storage solutions: A critical review. Int. J. Hydrog. Energy 2017, 42, 289-311. [CrossRef]

22. Sevilla, M.; Mokaya, R. Energy Storage applications of activated carbons: Supercapacitors and hydrogen storage. Energy Environ. Sci. 2014, 7, 1250-1280. [CrossRef]

23. Sevilla, M.; Fuertes, A.B.; Mokaya, R. High Density Hydrogen storage in superactivated carbons from hydrothermally carbonized renewable organic materials. Energy Environ. Sci. 2011, 4, 1400-1410. [CrossRef]

24. Schaefer, S.; Jeder, A.; Sdanghi, G.; Gadonneix, P.; Abdedayem, A.; Izquierdo, M.T.; Maranzana, G.; Ouederni, A.; Celzard, A.; Fierro, V. Oxygen-Promoted Hydrogen Adsorption on Activated and Hybrid Carbon Materials. Int. J. Hydrog. Energy 2020. [CrossRef]

25. Yang, Z.; Xia, Y.; Mokaya, R. Enhanced hydrogen storage capacity of high surface area zeolite-like carbon materials. J. Am. Chem. Soc. 2007, 129, 1673-1679. [CrossRef]

26. Masika, E.; Mokaya, R. Exceptional gravimetric and volumetric hydrogen storage for densified zeolite templated carbons with high mechanical stability. Energy Environ. Sci. 2014, 7, 427-434. [CrossRef] 
27. Alam, N.; Mokaya, R. Evolution of optimal porosity for improved hydrogen storage in templated zeolite-like carbons. Energy Environ. Sci. 2010, 3, 1773-1781. [CrossRef]

28. Sevilla, M.; Foulston, R.; Mokaya, R. Superactivated carbide-derived carbons with high hydrogen storage capacity. Energy Environ. Sci. 2010, 3, 223-227. [CrossRef]

29. Poirier, E.; Chahine, R.; Bose, T.K. Hydrogen adsorption in carbon nanostructures. Int. J. Hydrog. Energy 2001, 26, 831-835. [CrossRef]

30. Yan, Y.; Lin, X.; Yang, S.; Blake, A.J.; Dailly, A.; Champness, N.R.; Hubberstey, P.; Schröder, M. Exceptionally High H 2 Storage by a metal-organic polyhedral framework. Chem. Commun. 2009, 1025-1027. [CrossRef]

31. Farha, O.K.; Yazaydın, A.Ö.; Eryazici, I.; Malliakas, C.D.; Hauser, B.G.; Kanatzidis, M.G.; Nguyen, S.T.; Snurr, R.Q.; Hupp, J.T. De novo synthesis of a metal-organic framework material featuring ultrahigh surface area and gas storage capacities. Nat. Chem. 2010, 2, 944-948. [CrossRef]

32. Furukawa, H.; Ko, N.; Go, Y.B.; Aratani, N.; Choi, S.B.; Choi, E.; Yazaydin, A.Ö.; Snurr, R.Q.; O’Keeffe, M.; Kim, J. Ultrahigh porosity in metal-organic frameworks. Science 2010, 329, 424-428. [CrossRef]

33. Suh, M.P.; Park, H.J.; Prasad, T.K.; Lim, D.-W. Hydrogen storage in metal-organic frameworks. Chem. Rev. 2012, 112, 782-835. [CrossRef] [PubMed]

34. Murray, L.J.; Dincă, M.; Long, J.R. Hydrogen Storage in metal-organic frameworks. Chem. Soc. Rev. 2009, 38, 1294-1314. [CrossRef] [PubMed]

35. Ding, S.-Y.; Wang, W. Covalent Organic Frameworks (COFs): From Design to applications. Chem. Soc. Rev. 2013, 42, 548-568. [CrossRef]

36. Han, S.S.; Furukawa, H.; Yaghi, O.M.; Goddard Iii, W.A. Covalent organic frameworks as exceptional hydrogen storage materials. J. Am. Chem. Soc. 2008, 130, 11580-11581. [CrossRef]

37. Dalebrook, A.F.; Gan, W.; Grasemann, M.; Moret, S.; Laurenczy, G. Hydrogen storage: Beyond conventional methods. Chem. Commun. 2013, 49, 8735-8751. [CrossRef]

38. Liu, Y.-Y.; Zeng, J.-L.; Zhang, J.; Xu, F.; Sun, L.-X. Improved hydrogen storage in the modified metal-organic frameworks by hydrogen spillover effect. Int. J. Hydrog. Energy 2007, 32, 4005-4010. [CrossRef]

39. Zhu, Q.-L.; Xu, Q. Metal-organic framework composites. Chem. Soc. Rev. 2014, 43, 5468-5512. [CrossRef] [PubMed]

40. Xia, Y.; Yang, Z.; Zhu, Y. Porous carbon-based materials for hydrogen storage: Advancement and challenges. J. Mater. Chem. A 2013, 1, 9365-9381. [CrossRef]

41. Moradi, R.; Groth, K.M. Hydrogen storage and delivery: Review of the state of the art technologies and risk and reliability analysis. Int. J. Hydrog. Energy 2019, 44, 12254-12269. [CrossRef]

42. Blankenship, T.S.; Mokaya, R. Cigarette Butt-derived carbons have ultra-high surface area and unprecedented hydrogen storage capacity. Energy Environ. Sci. 2017, 10, 2552-2562. [CrossRef]

43. Bader, N.; Ouederni, A. Optimization of biomass-based carbon materials for hydrogen storage. J. Energy Storage 2016, 5, 77-84. [CrossRef]

44. Agarwal, R.K.; Noh, J.S.; Schwarz, J.A.; Davini, P. Effect of surface acidity of activated carbon on hydrogen storage. Carbon 1987, 25, 219-226. [CrossRef]

45. Fierro, V.; Zhao, W.; Izquierdo, M.T.; Aylon, E.; Celzard, A. Adsorption and compression contributions to hydrogen storage in activated anthracites. Int. J. Hydrog. Energy 2010, 35, 9038-9045. [CrossRef]

46. Samantaray, S.S.; Mangisetti, S.R.; Ramaprabhu, S. Investigation of room temperature hydrogen storage in biomass derived activated carbon. J. Alloys Compd. 2019, 789, 800-804. [CrossRef]

47. Sun, Y.; Webley, P.A. Preparation of activated carbons from corncob with large specific surface area by a variety of chemical activators and their application in gas storage. Chem. Eng. J. 2010, 162, 883-892. [CrossRef]

48. Balathanigaimani, M.S.; Haider, M.B.; Jha, D.; Kumar, R.; Lee, S.J.; Shim, W.G.; Shon, H.K.; Kim, S.C.; Moon, H. Nanostructured biomass based carbon materials from beer lees for hydrogen storage. J. Nanosci. Nanotechnol. 2018, 18, 2196-2199. [CrossRef]

49. Chen, T.; Zhou, Y.; Luo, L.; Wu, X.; Li, Z.; Fan, M.; Zhao, W. Preparation and characterization of heteroatom self-doped activated biocarbons as hydrogen storage and supercapacitor electrode materials. Electrochim. Acta 2019, 325, 134941. [CrossRef]

50. Zhao, W.; Luo, L.; Wang, H.; Fan, M. Synthesis of Bamboo-based activated carbons with super-high specific surface area for hydrogen storage. BioResources 2017, 12, 1246-1262. [CrossRef]

51. Akasaka, H.; Takahata, T.; Toda, I.; Ono, H.; Ohshio, S.; Himeno, S.; Kokubu, T.; Saitoh, H. Hydrogen storage ability of porous carbon material fabricated from coffee bean wastes. Int. J. Hydrog. Energy 2011, 36, 580-585. [CrossRef]

52. Heo, Y.-J.; Park, S.-J. Synthesis of Activated carbon derived from rice husks for improving hydrogen storage capacity. J. Ind. Eng. Chem. 2015, 31, 330-334. [CrossRef]

53. Yang, R.; Liu, G.; Li, M.; Zhang, J.; Hao, X. Preparation and $\mathrm{N}_{2}, \mathrm{CO}_{2}$ and $\mathrm{H}_{2}$ Adsorption of super activated carbon derived from biomass source hemp (Cannabis Sativa L.) stem. Microporous Mesoporous Mater. 2012, 158, 108-116. [CrossRef]

54. Huang, C.-C.; Chen, H.-M.; Chen, C.-H. Hydrogen adsorption on modified activated carbon. Int. J. Hydrog. Energy 2010, 35, 2777-2780. [CrossRef]

55. Wróbel-Iwaniec, I.; Díez, N.; Gryglewicz, G. Chitosan-based highly activated carbons for hydrogen storage. Int. J. Hydrog. Energy 2015, 40, 5788-5796. [CrossRef] 
56. Ma, L.; Li, J.; Ma, X. Preparation and adsorption of $\mathrm{CO}_{2}$ and $\mathrm{H}_{2}$ by Activated carbon hollow fibers from rubber wood (hevea brasiliensis). BioResources 2019, 14, 11.

57. Zheng, Z.; Gao, Q.; Jiang, J. High hydrogen uptake capacity of mesoporous nitrogen-doped carbons activated using potassium hydroxide. Carbon 2010, 48, 2968-2973. [CrossRef]

58. Wang, J.; Senkovska, I.; Kaskel, S.; Liu, Q. Chemically activated fungi-based porous carbons for hydrogen storage. Carbon 2014 75, 372-380. [CrossRef]

59. Bader, N.; Zacharia, R.; Abdelmottaleb, O.; Cossement, D. How the Activation process modifies the hydrogen storage behavior of biomass-derived activated carbons. J. Porous Mater. 2018, 25, 221-234. [CrossRef]

60. Zhang, C.; Geng, Z.; Cai, M.; Zhang, J.; Liu, X.; Xin, H.; Ma, J. Microstructure regulation of super activated carbon from biomass source corncob with enhanced hydrogen uptake. Int. J. Hydrog. Energy 2013, 38, 9243-9250. [CrossRef]

61. Ramesh, T.; Rajalakshmi, N.; Dhathathreyan, K.S. Synthesis and characterization of activated carbon from jute fibers for hydrogen storage. Renew. Energy Environ. Sustain. 2017, 2, 4. [CrossRef]

62. Ding, F.; Yakobson, B.I. Challenges in hydrogen adsorptions: From physisorption to chemisorption. Front. Phys. 2011, 6, 142-150. [CrossRef]

63. Panella, B.; Hirscher, M.; Roth, S. Hydrogen adsorption in different carbon nanostructures. Carbon 2005, 43, 2209-2214. [CrossRef]

64. Panella, B.; Hirscher, M.; Pütter, H.; Müller, U. Hydrogen adsorption in metal-organic frameworks: Cu-MOFs and Zn-MOFs compared. Adv. Funct. Mater. 2006, 16, 520-524. [CrossRef]

65. Wong-Foy, A.G.; Matzger, A.J.; Yaghi, O.M. Exceptional $\mathrm{H}_{2}$ Saturation uptake in microporous metal-organic frameworks. J. Am. Chem. Soc. 2006, 128, 3494-3495. [CrossRef] [PubMed]

66. Sur, U.K. Graphene: A Rising star on the horizon of materials science. Int. J. Electrochem. 2012, 2012, 237689. [CrossRef]

67. Czakkel, O.; Nagy, B.; Dobos, G.; Fouquet, P.; Bahn, E.; László, K. Static and Dynamic studies of hydrogen adsorption on nanoporous carbon gels. Int. J. Hydrog. Energy 2019, 44, 18169-18178. [CrossRef]

68. Yushin, G.; Dash, R.; Jagiello, J.; Fischer, J.E.; Gogotsi, Y. Carbide-derived carbons: Effect of pore size on hydrogen uptake and heat of adsorption. Adv. Funct. Mater. 2006, 16, 2288-2293. [CrossRef]

69. Gogotsi, Y.; Portet, C.; Osswald, S.; Simmons, J.M.; Yildirim, T.; Laudisio, G.; Fischer, J.E. Importance of pore size in high-pressure hydrogen storage by porous carbons. Int. J. Hydrog. Energy 2009, 34, 6314-6319. [CrossRef]

70. Cabria, I.; López, M.J.; Alonso, J.A. The Optimum average nanopore size for hydrogen storage in carbon nanoporous materials. Carbon 2007, 45, 2649-2658. [CrossRef]

71. Sevilla, M.; Mokaya, R.; Fuertes, A.B. Ultrahigh surface area polypyrrole-based carbons with superior performance for hydrogen storage. Energy Environ. Sci. 2011, 4, 2930-2936. [CrossRef]

72. Texier-Mandoki, N.; Dentzer, J.; Piquero, T.; Saadallah, S.; David, P. Hydrogen storage in activated carbon materials: Role of the nanoporous texture. Carbon 2004, 42, 2744-2747. [CrossRef]

73. Lee, S.-Y.; Park, S.-J. Effect of temperature on activated carbon nanotubes for hydrogen storage behaviors. Int. J. Hydrog. Energy 2010, 35, 6757-6762. [CrossRef]

74. Park, S.-J.; Lee, S.-Y. Hydrogen storage behaviors of platinum-supported multi-walled carbon nanotubes. Int. J. Hydrog. Energy 2010, 35, 13048-13054. [CrossRef]

75. Zhao, W.; Fierro, V.; Zlotea, C.; Aylon, E.; Izquierdo, M.T.; Latroche, M.; Celzard, A. Optimization of activated carbons for hydrogen storage. Int. J. Hydrog. Energy 2011, 36, 11746-11751. [CrossRef]

76. Pedicini, R.; Maisano, S.; Chiodo, V.; Conte, G.; Policicchio, A.; Agostino, R.G. Posidonia oceanica and wood chips activated carbon as interesting materials for hydrogen storage. Int. J. Hydrog. Energy 2020, S0360319920310922. [CrossRef]

77. Xiao, Y.; Dong, H.; Long, C.; Zheng, M.; Lei, B.; Zhang, H.; Liu, Y. Melaleuca Bark based porous carbons for hydrogen storage. Int. J. Hydrog. Energy 2014, 39, 11661-11667. [CrossRef]

78. Zhang, J.; Gao, J.; Chen, Y.; Hao, X.; Jin, X. Characterization, preparation, and reaction mechanism of hemp stem based activated carbon. Results Phys. 2017, 7, 1628-1633. [CrossRef]

79. Li, S.; Han, K.; Li, J.; Li, M.; Chunmei, L. preparation and characterization of super activated carbon produced from gulfweed by koh activation. Microporous Mesoporous Mater. 2017, 243, 291-300. [CrossRef]

80. Ateş, F.; Özcan, Ö. Preparation and characterization of activated carbon from poplar sawdust by chemical activation: Comparison of different activating agents and carbonization temperature. Eur. J. Eng. Res. Sci. 2018, 3, 6-11. [CrossRef]

81. El-Hendawy, A.-N.A. An insight into the $\mathrm{KOH}$ activation mechanism through the production of microporous activated carbon for the removal of Pb2+ cations. Appl. Surf. Sci. 2009, 255, 3723-3730. [CrossRef]

82. Xiaojing Chen, H.Z.; Xiaojing Chen, H.Z. Activation mechanisms on potassium hydroxide enhanced microstructures development of coke powder. Chin. J. Chem. Eng. 2020, 28, 299-306. [CrossRef]

83. Saha, N.; Xin, D.; Chiu, P.C.; Reza, M.T. Effect of pyrolysis temperature on acidic oxygen-containing functional groups and electron storage capacities of pyrolyzed hydrochars. ACS Sustain. Chem. Eng. 2019, 7, 8387-8396. [CrossRef]

84. Bhomick, P.C.; Supong, A.; Karmaker, R.; Baruah, M.; Pongener, C.; Sinha, D. Activated carbon synthesized from biomass material using single-step koh activation for adsorption of fluoride: Experimental and theoretical investigation. Korean J. Chem. Eng. 2019, 36, 551-562. [CrossRef]

85. Wang, Y.; Hu, Y.; Zhao, X.; Wang, S.; Xing, G. Comparisons of biochar properties from wood material and crop residues at different temperatures and residence times. Energy Fuels 2013, 27, 5890-5899. [CrossRef] 
86. Maisano, S.; Urbani, F.; Mondello, N.; Chiodo, V. Catalytic pyrolysis of mediterranean sea plant for bio-oil production. Int. J. Hydrog. Energy 2017, 42, 28082-28092. [CrossRef]

87. Spokas, K.A. Review of the stability of biochar in soils: Predictability of O:C molar ratios. Carbon Manag. 2010, 1, 289-303. [CrossRef]

88. Cataldo, S.; Chiodo, V.; Crea, F.; Maisano, S.; Milea, D.; Pettignano, A. Biochar from byproduct to high value added material—A new adsorbent for toxic metal ions removal from aqueous solutions. J. Mol. Liq. 2018, 271, 481-489. [CrossRef]

89. Shayeganfar, F.; Shahsavari, R. Oxygen- and lithium-doped hybrid boron-nitride/carbon networks for hydrogen storage. Langmuir 2016, 32, 13313-13321. [CrossRef]

90. Georgakis, M.; Stavropoulos, G.; Sakellaropoulos, G.P. Molecular dynamics study of hydrogen adsorption in carbonaceous microporous materials and the effect of oxygen functional groups. Int. J. Hydrog. Energy 2007, 32, 1999-2004. [CrossRef]

91. Llorens, J.; Pera-Titus, M. Influence of surface heterogeneity on hydrogen adsorption on activated carbons. Colloids Surf. A: Physicochem. Eng. Asp. 2009, 350, 63-72. [CrossRef]

92. Wang, H.; Gao, Q.; Hu, J. High hydrogen storage capacity of porous carbons prepared by using activated carbon. J. Am. Chem. Soc. 2009, 131, 7016-7022. [CrossRef]

93. Qu, D. Investigation of hydrogen physisorption active sites on the surface of porous carbonaceous materials. Chem. A Eur. J. 2008, 14, 1040-1046. [CrossRef]

94. 18th World Hydrogen Energy Conference 2010_WHEC 2010: Proceedings. 4: Parallel Sessions Book: Storage Systems, Policy Perspectives, Initiatives and Cooperations; Stolten, D.; Grube, T. (Eds.) Schriften des Forschungszentrums Jülich Reihe Energie \& Umwelt; Forschungszentrum, IEF-3: Jülich, Germany, 2010; ISBN 978-3-89336-654-5.

95. Bleda-Martínez, M.J.; Pérez, J.M.; Linares-Solano, A.; Morallón, E.; Cazorla-Amorós, D. Effect of Surface chemistry on electrochemical storage of hydrogen in porous carbon materials. Carbon 2008, 46, 1053-1059. [CrossRef]

96. Andrews, J.; Shabani, B. The role of hydrogen in a global sustainable energy strategy. Wires Energy Environ. 2014, 3, 474-489. [CrossRef]

97. Bader, N.; Ouederni, A. Functionalized and metal-doped biomass-derived activated carbons for energy storage application. J. Energy Storage 2017, 13, 268-276. [CrossRef]

98. Liu, X.; Zhang, C.; Geng, Z.; Cai, M. High-pressure hydrogen storage and optimizing fabrication of corncob-derived activated carbon. Microporous Mesoporous Mater. 2014, 194, 60-65. [CrossRef]

99. Ramesh, T.; Rajalakshmi, N.; Dhathathreyan, K.S. Activated carbons derived from tamarind seeds for hydrogen storage. J. Energy Storage 2015, 4, 89-95. [CrossRef]

100. Md Arshad, S.H.; Ngadi, N.; Aziz, A.A.; Amin, N.S.; Jusoh, M.; Wong, S. Preparation of activated carbon from empty fruit bunch for hydrogen storage. J. Energy Storage 2016, 8, 257-261. [CrossRef]

101. Schlichtenmayer, M.; Hirscher, M. The usable capacity of porous materials for hydrogen storage. Appl. Phys. A 2016, 122, 379. [CrossRef]

102. Chahine, R.; Bose, T. Low-Pressure Adsorption Storage of Hydrogen. Int. J. Hydrog. Energy 1994, 19, 161-164. [CrossRef]

103. Schmitz, B.; Müller, U.; Trukhan, N.; Schubert, M.; Férey, G.; Hirscher, M. Heat of adsorption for hydrogen in microporous high-surface-area materials. ChemPhysChem 2008, 9, 2181-2184. [CrossRef]

104. Jhung, S.H.; Kim, H.-K.; Yoon, J.W.; Chang, J.-S. Low-temperature adsorption of hydrogen on nanoporous aluminophosphates: effect of pore size. J. Phys. Chem. B 2006, 110, 9371-9374. [CrossRef] [PubMed]

105. Chun, H.; Dybtsev, D.N.; Kim, H.; Kim, K. Synthesis, X-ray crystal structures, and gas sorption properties of pillared square grid nets based on paddle-wheel motifs: Implications for hydrogen storage in porous materials. Chem. A Eur. J. 2005, 11, 3521-3529. [CrossRef]

106. Bhatia, S.K.; Myers, A.L. Optimum conditions for adsorptive storage. Langmuir 2006, 22, 1688-1700. [CrossRef]

107. Yürüm, Y.; Taralp, A.; Veziroglu, T.N. Storage of hydrogen in nanostructured carbon materials. Int. J. Hydrog. Energy 2009, 34, 3784-3798. [CrossRef]

108. Zubizarreta, L.; Arenillas, A.; Pis, J.J. Carbon materials for $\mathrm{H}_{2}$ storage. Int. J. Hydrog. Energy 2009, 34, 4575-4581. [CrossRef]

109. Figueroa-Torres, M.Z.; Domínguez-Ríos, C.; Cabañas-Moreno, J.G.; Vega-Becerra, O.; Aguilar-Elguézabal, A. The synthesis of ni-activated carbon nanocomposites via electroless deposition without a surface pretreatment as potential hydrogen storage materials. Int. J. Hydrog. Energy 2012, 37, 10743-10749. [CrossRef]

110. Dincă, M.; Long, J.R. Hydrogen Storage in microporous metal-organic frameworks with exposed metal sites. Angew. Chem. Int. Ed. Engl. 2008, 47, 6766-6779. [CrossRef]

111. Zieliński, M.; Wojcieszak, R.; Monteverdi, S.; Mercy, M.; Bettahar, M.M. Hydrogen Storage in nickel catalysts supported on activated carbon. Int. J. Hydrog. Energy 2007, 32, 1024-1032. [CrossRef]

112. Zubizarreta, L.; Menéndez, J.A.; Pis, J.J.; Arenillas, A. Improving hydrogen storage in ni-doped carbon nanospheres. Int. J. Hydrog. Energy 2009, 34, 3070-3076. [CrossRef]

113. Chen, C.-H.; Huang, C.-C. Enhancement of hydrogen spillover onto carbon nanotubes with defect feature. Microporous Mesoporous Mater. 2008, 109, 549-559. [CrossRef]

114. Li, Y.; Yang, R.T.; Liu, C.; Wang, Z. Hydrogen storage on carbon doped with platinum nanoparticles using plasma reduction. Ind. Eng. Chem. Res. 2007, 46, 8277-8281. [CrossRef] 
115. Wang, Z.; Yang, R.T. Enhanced hydrogen storage on pt-doped carbon by plasma reduction. J. Phys. Chem. C 2010, 114, 5956-5963. [CrossRef]

116. Zacharia, R.; Rather, S.; Hwang, S.W.; Nahm, K.S. Spillover of physisorbed hydrogen from sputter-deposited arrays of platinum nanoparticles to multi-walled carbon nanotubes. Chem. Phys. Lett. 2007, 434, 286-291. [CrossRef]

117. Hsieh, C.-T.; Chou, Y.-W.; Lin, J.-Y. Fabrication and electrochemical activity of ni-attached carbon nanotube electrodes for hydrogen storage in alkali electrolyte. Int. J. Hydrog. Energy 2007, 32, 3457-3464. [CrossRef]

118. Jin, G.-P.; Ding, Y.-F.; Zheng, P.-P. Electrodeposition of nickel nanoparticles on functional MWCNT surfaces for ethanol oxidation. J. Power Sources 2007, 166, 80-86. [CrossRef]

119. Bittencourt, C.; Felten, A.; Ghijsen, J.; Pireaux, J.J.; Drube, W.; Erni, R.; Van Tendeloo, G. Decorating carbon nanotubes with nickel nanoparticles. Chem. Phys. Lett. 2007, 436, 368-372. [CrossRef]

120. Liu, X.-W.; Sun, T.-J.; Hu, J.-L.; Wang, S.-D. Composites of metal-organic frameworks and carbon-based materials: Preparations, functionalities and applications. J. Mater. Chem. A 2016, 4, 3584-3616. [CrossRef]

121. Ali, M.; El-Sai, N.; Girgis, B. Evaluation and modeling of high surface area activated carbon from date frond and application on some pollutants. Int. J. Comput. Eng. Res. 2014, 4, 70-78.

122. Tseng, R.-L. Physical and chemical properties and adsorption type of activated carbon prepared from plum kernels by $\mathrm{NaOH}$ activation. J. Hazard. Mater. 2007, 147, 1020-1027. [CrossRef]

123. Ruiz-Fernández, M.; Alexandre-Franco, M.; Fernández-González, C.; Gómez-Serrano, V. Development of activated carbon from vine shoots by physical and chemical activation methods. Some insight into activation mechanisms. Adsorption 2011, 17, 621-629. [CrossRef]

124. Parambhath, V.B.; Nagar, R.; Ramaprabhu, S. Effect of nitrogen doping on hydrogen storage capacity of palladium decorated graphene. Langmuir 2012, 28, 7826-7833. [CrossRef]

125. Chung, T.-Y.; Tsao, C.-S.; Tseng, H.-P.; Chen, C.-H.; Yu, M.-S. Effects of Oxygen functional groups on the enhancement of the hydrogen spillover of Pd-doped activated carbon. J. Colloid Interface Sci. 2015, 441, 98-105. [CrossRef]

126. Zhao, W.; Luo, L.; Chen, T.; Li, Z.; Zhang, Z.; Wang, H.; Rao, J.; Feo, L.; Fan, M. Synthesis and characterization of Pt-N-doped activated biocarbon composites for hydrogen storage. Compos. Part B Eng. 2019, 161, 464-472. [CrossRef]

127. Psofogiannakis, G.M.; Froudakis, G.E. Fundamental studies and perceptions on the spillover mechanism for hydrogen storage. Chem. Commun. 2011, 47, 7933-7943. [CrossRef]

128. Psofogiannakis, G.M.; Steriotis, T.A.; Bourlinos, A.B.; Kouvelos, E.P.; Charalambopoulou, G.C.; Stubos, A.K.; Froudakis, G.E. Enhanced hydrogen storage by spillover on metal-doped carbon foam: An experimental and computational study. Nanoscale 2011, 3, 933-936. [CrossRef] [PubMed]

129. Li, Q.; Lueking, A.D. Effect of surface oxygen groups and water on hydrogen spillover in Pt-doped activated carbon. J. Phys. Chem. C 2011, 115, 4273-4282. [CrossRef]

130. Wang, Z.; Yang, F.H.; Yang, R.T. Enhanced hydrogen spillover on carbon surfaces modified by oxygen plasma. J. Phys. Chem. C 2010, 114, 1601-1609. [CrossRef]

131. Geng, Z.; Wang, D.; Zhang, C.; Zhou, X.; Xin, H.; Liu, X.; Cai, M. Spillover enhanced hydrogen uptake of Pt/Pd doped corncob-derived activated carbon with ultra-high surface area at high pressure. Int. J. Hydrog. Energy 2014, 39, 13643-13649. [CrossRef]

132. Adams, B.D.; Ostrom, C.K.; Chen, S.; Chen, A. High-performance Pd-based hydrogen spillover catalysts for hydrogen storage. J. Phys. Chem. C 2010, 114, 19875-19882. [CrossRef]

133. Wang, L.; Yang, R.T. New sorbents for hydrogen storage by hydrogen spillover-A review. Energy Environ. Sci. 2008, 1, 268-279. [CrossRef]

134. Wang, Y.; Wang, K.; Guan, C.; He, Z.; Lu, Z.; Chen, T.; Liu, J.; Tan, X.; Yang Tan, T.T.; Li, C.M. Surface Functionalization-enhanced spillover effect on hydrogen storage of Ni-B nanoalloy-doped activated carbon. Int. J. Hydrog. Energy 2011, 36, 13663-13668. [CrossRef]

135. Lachawiec, A.J.; Qi, G.; Yang, R.T. Hydrogen storage in nanostructured carbons by spillover: bridge-building enhancement. Langmuir 2005, 21, 11418-11424. [CrossRef]

136. Wang, L.; Yang, R.T. Molecular hydrogen and spiltover hydrogen storage on high surface area carbon sorbents. Carbon 2012, 50, 3134-3140. [CrossRef]

137. Li, Y.; Yang, R.T. Hydrogen storage on platinum nanoparticles doped on superactivated carbon. J. Phys. Chem. C 2007, 111, 11086-11094. [CrossRef]

138. Zubizarreta, L.; Menéndez, J.A.; Job, N.; Marco-Lozar, J.P.; Pirard, J.P.; Pis, J.J.; Linares-Solano, A.; Cazorla-Amorós, D.; Arenillas, A. Ni-doped carbon xerogels for $\mathrm{H}_{2}$ storage. Carbon 2010, 48, 2722-2733. [CrossRef]

139. Zhu, J.; Cheng, J.; Dailly, A.; Cai, M.; Beckner, M.; Shen, P.K. One-pot synthesis of pd nanoparticles on ultrahigh surface area 3D porous carbon as hydrogen storage materials. Int. J. Hydrog. Energy 2014, 39, 14843-14850. [CrossRef] 